\title{
Bethune: consummate humanitarian and man of action
}

\author{
Norman Bethune \\ Adrienne Clarkson \\ Penguin Canada, Extraordinary Canadians \\ Series; 2009. 204 pp $\$ 26.00$
}

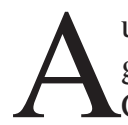
uthor, journalist and former governor general Adrienne Clarkson brings a fresh perspective to this compelling and accessible introduction to Dr. Norman Bethune (1890-1939), who is arguably the world's most famous surgeon, known for his humanitarian internationalism by hundreds of millions in China.

Bethune's fascinating story is well told in this slender volume. Clarkson shows us Bethune as a young man, moving from the logging camps of Northern Ontario to his training in Toronto and his practise in Detroit, Michigan, and Montréal, Quebec. She describes the frustrating intensity that led him to marry and divorce the same woman twice, and his never smooth interactions with his colleagues. Many of his contradictions are on display: the Montréal socialist willingly courting the Montréal socialites, promoting free medical care while touting his own line of surgical instruments. All this contributes to our understanding of the man, the doctor and the Canadian.

Clarkson also makes innumerable connections that secure Bethune's ideas within Canada's social fabric. Bethune was a man of action, so when he wrote "Let us redefine medical ethics, not as a code of professional etiquette between doctors but as a code of fundamental morality and justice between medicine and the people" he also promptly set about to reform health care in Montréal as a publicly funded good. His proposals were met by what Clarkson characterizes as "resounding indifference from the medical profession, the political class, and the public; anything that smacked of publicly funded health care carried with it the subtext of Russian Communism and was not looked upon kindly."

Clarkson does us the favour of exam-

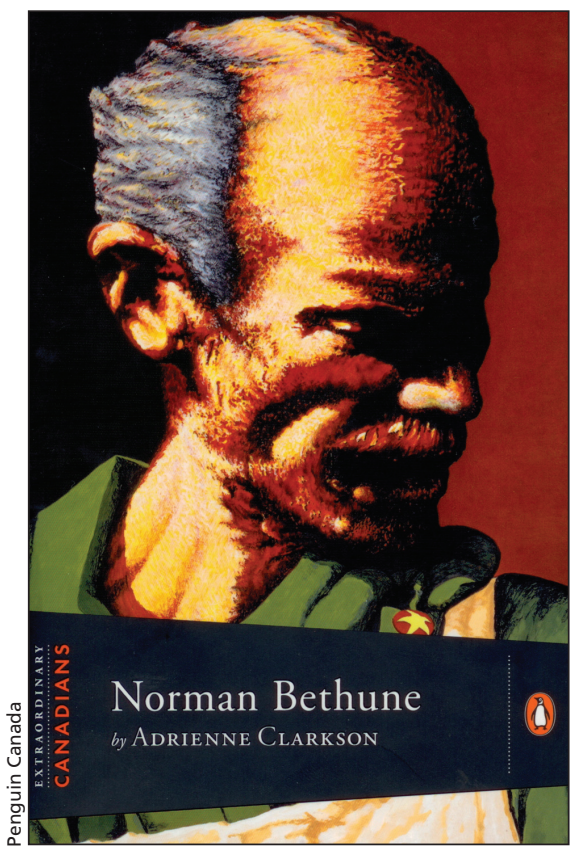

ining Bethune's life and ideas from today's perspective, so that we know him as a man who was decades ahead of his time, a man who anticipated the necessary changes in health care that occurred well after his lifetime. Bethune had little of the patience required to see his ethical insights into how medicine should work actually put into practice. Rather, he had to act, and act quickly, quickly enough that even other surgeons soon tired of working with him. Only the international stage was big enough for Bethune.

Blood-banking is one example of his big-picture medical innovation. North America's first blood bank was established at Cook County Hospital in Chicago, Illinois, one year after Bethune pioneered blood banking as a supplement to the then-common direct transfusion technique. Bethune's advances were made in a mobile transfusion unit that he founded to support the Spanish resistance to fascism. He had little training or experience in transfusion medicine and was regularly coping with bombing raids and humanitarian needs during his time in the Spanish Civil War (1936-7). This turmoil created sufficient motivation and challenge to keep him on this task that ultimately saved hundreds of lives.
Bethune is best known, however, for his internationalism and humanitarianism, particularly for his voluntary service, from 1938 to his death in 1939, in Mao Zedong's Eighth Route Army in their struggle during the Second SinoJapanese War. In addition to performing battlefield surgical operations, he established training for physicians, nurses and others. Mao upheld his humanitarian and social ideals, and wrote of them in his essay In Memory of Norman Bethune, as an example for all of China. And indeed, he became known to hundreds of millions in that country.

Yet Bethune's communist connections have long kept him from recognition among the pantheon of influential Canadians, so it's gratifying to see him included in this new series of biographies from Penguin. The series weaves together the ideas that matter in Canada today, highlighting the extraordinary lives that have moulded our country.

Bethune changed the world with his idea that medical and surgical care must be accessible to those most in need. Canada has done well for itself by putting these ideas into practice within our borders, but we have far to go in putting these ideas into practice across the globe. Perhaps Canada will play a leading role in global health and international surgery worthy of Bethune's legacy. Clarkson shows us clearly who he was, why he mattered, how he contributed to our Canada of today and why his ideas still matter as we mutually invent our future.

\section{Andrew William Howard MD \\ Director \\ Office of International Surgery \\ University of Toronto \\ Toronto, Ont.}

Dr. Howard hosts an annual international surgical meeting named in Norman Bethune's honour. While attendees are not Bethune scholars, they are interested in surgery for human development and believe that Bethune's ideals about humanitarianism and internationalism strike a chord with many doctors. 